\title{
Spondias pinnata bark extract- an ameliorator of inflammatory derangement in etoposide induced mucositis: An experimental approach
}

\author{
Aradhana Marathe ${ }^{1}$ (D), Gayathri M. Rao ${ }^{1}$ (D) and M. Chakrapani² ${ }^{(D)}$ \\ 1. Department of Biochemistry, Kasturba Medical College, Mangalore, Manipal Academy of Higher Education, Manipal, \\ Karnataka, India; 2. Department of Medicine, Kasturba Medical College, Mangalore, Manipal Academy of Higher \\ Education, Manipal, Karnataka, India. \\ Corresponding author: Gayathri M. Rao, e-mail: gayathri.rao@manipal.edu \\ Co-authors: AM: aradhana.marathe@manipal.edu, MC: chakrapani.m@manipal.edu \\ Received: 15-03-2021, Accepted: 02-06-2021, Published online: 15-07-2021
}

doi: www.doi.org/10.14202/vetworld.2021.1822-1828 How to cite this article: Marathe A, Rao GM, Chakrapani M (2021) Spondias pinnata bark extract- an ameliorator of inflammatory derangement in etoposide induced mucositis: An experimental approach, Veterinary World, 14(7): 1822-1828.

\begin{abstract}
Background and Aim: Mucositis, one of the vulnerabilities of chemotherapy, affects the physiological activities and therapeutic strategies of patients because it can affect the normal cell population. Etoposide is a commonly used chemotherapeutic agent for cancers such as oral, lung, and gastrointestinal. In addition to the abnormal metabolic processes in the body caused by tumorigenesis, new metabolic alterations can occur, such as oxidative stress, antioxidant imbalance, and inflammatory reactions, all of which can contribute to existing patient vulnerability. Therapeutic adjuvants can help overcome these toxic effects. Spondias pinnata is a tropical tree omnipresent in the coastal and Western Ghat section of India that is used for culinary purposes and as a local analgesic. Therefore, we aimed to study the anti-inflammatory effects of $S$. pinnata in an etoposide-induced mucositis rat model.
\end{abstract}

Materials and Methods: Small intestinal tissue homogenates from albino Wistar rats were used to estimate the levels of glutathione $(\mathrm{GSH})$ and nitric oxide $(\mathrm{NO})$, and activities of total antioxidant (TAO), myeloperoxidase (MPO) and $\mathrm{Na}^{+}-\mathrm{K}^{+}$ ATPase. The animals were grouped into: (1) normal control, (2) etoposide-induced mucositis (65 mg/kg bodyweight, single IP dose), (3) S. pinnata control group, and (4) etoposide followed by $S$. pinnata bark extract ( $200 \mathrm{mg} / \mathrm{kg}$ bodyweight, once in a day). Animals were sacrificed after 24, 48, 72, and $96 \mathrm{~h}$ and compared with that of the normal control group ( $\mathrm{n}=6$ ). Statistical analysis was performed using EZR software.

Results: We observed a significant decrease in the TAO and GSH levels with a marked increase in NO, MPO, and Na ${ }^{+} \mathrm{K}^{+}$ATPase activity in the mucositis group. A tendency to recover from the decreased TAO and GSH levels existed in the treated group, showing the protective effects of $S$. pinnata bark extract against mucositis. In addition, this extract also showed anti-inflammatory effects as reflected by the recovery in MPO levels at the end of $96 \mathrm{~h}$. Maintenance of $\mathrm{Na}^{+}-\mathrm{K}^{+}$ATPase activity in the treated group demonstrates the protective effects of the extract against the increased levels observed in the etoposide-induced mucositis group.

Conclusion: This study revealed the protective effects of $S$. pinnata bark extract against the oxidative and inflammatory changes that occurred during the development ofmucositis. This would decrease the pathological burden during chemotherapy and prevent any hurdles in therapeutic modalities.

Keywords: etoposide, mucositis, oxidative and inflammatory markers.

\section{Introduction}

Chemotherapy is the most common therapeutic strategy used worldwide during cancer treatment. Although this therapy is most promising, it attacks several normal body processes, worsening patients' physiological vulnerability. Mucositis is one such outcome [1]. Etoposide, as an epipodophyllotoxin derivative and a topoisomerase-II inhibitor, is widely used in the treatment of various cancers [2].

Almost all chemotherapeutic agents cause mucotoxic effects that can make the life of cancer patients more miserable. Mucositis is the painful ulceration of

Copyright: Marathe, et al. Open Access. This article is distributed under the terms of the Creative Commons Attribution 4.0 International License (http://creativecommons.org/licenses/ by/4.0/), which permits unrestricted use, distribution, and reproduction in any medium, provided you give appropriate credit to the original author(s) and the source, provide a link to the Creative Commons license, and indicate if changes were made. The Creative Commons Public Domain Dedication waiver (http:// creativecommons.org/publicdomain/zero/1.0/) applies to the data made available in this article, unless otherwise stated. the mucosal lining right from the oral cavity distributed across the gastrointestinal tract (GIT), affecting its normal functioning. Sonis [3] has explicitly divided the sequence of mucositis into five stages: Initiation, primary damage response, signal amplification, ulceration, and healing.

The pathophysiology of mucositis is still obscure; its occurrence lasts for about 3 weeks; and are of two types: direct and indirect. Chemotherapy interferes with the normal turnover of intestinal epithelial cells through one or both of these processes $[4,5]$. Generation of reactive oxygen species (ROS) happens during the initiation phase which, in turn, elicits the inflammatory reactions leading to the ablation of the epithelium and ulceration of the GIT, causing infiltration of microbiota. In the final phase, although healing occurs, the magnitude of the recovery depends on the extent of damage caused to the epithelium of the GIT, as well as the available defensive mechanisms $[6,7]$. Thus, an inflammatory cascade is 
exacerbated by the oxidative damage caused during mucositis.

Nitric oxide (NO), a principal inflammatory marker, is synthesized by inducible NO synthase (iNOS) during inflammation. Myeloperoxidase (MPO), the activity of which increases during systemic inflammation, also has been found to upregulate the activity of iNOS [8]. Reduced glutathione (GSH) and total antioxidant (TAO) activity are basic parameters that can help explain antioxidant status. Diarrhea is a common complication associated with mucositis, which alters the osmotic and ionic balance in the gut. $\mathrm{Na}^{+}-\mathrm{K}^{+}$ATPase, an active enzyme of the intestinal epithelium, is required for the maintenance of the electrolyte balance attributed to its increased activity during chronic and acute inflammatory conditions of the GIT as well as is a signal transducer for muscle and nerve conduction $[9,10] . \mathrm{Na}^{+}-\mathrm{K}^{+}$ATPase, which results in the production of pro-inflammatory cytokines and various other chemokines such as tumor necrosis factor- $\alpha$, interleukin- 5 , nuclear factor- $\mathrm{\kappa B}$ through mitogen-activated protein kinase, and p38 associated pathways $[11,12]$, is now being treated as a target parameter in anticancer therapy.

Chemotherapy not only can pose a socioeconomic burden on patients but also can lead to psychological encumbrance due to the inexhaustible metabolic changes and side effects. Therefore, considering the infinitesimal molecular changes in an individual are necessary. In addition, several oxidative fluctuations followed by inflammatory archetypes can differ from one patient to another. The use of chemotherapeutic regimens, with their diverse combinations, action mechanisms, exposure, and patient capacity to withstand these, has become a crucial area of concern $[13,14]$.

Spondias pinnata, also called the hog plum, is a deciduous tree belonging to the Anacardaciae family. The tree is found along the Western Ghats and the coastal belt of India and is used as a culinary and medicinal supplement. Methanolic and ethanolic bark extract studies with this plant have revealed the antibacterial, anticancer, anti-helminthic, analgesic, and antipyretic properties attributed to the presence of polyphenolic compounds [15].

Many naturally occurring herbs and herbal products have been used to relieve the severity of mucositis caused by chemotherapy. With this basic knowledge, we intended to study the protective effect of $S$. pinnata for its anti-inflammatory effect if any.

\section{Materials and Methods}

\section{Ethical approval}

Institution's Animal Ethics Committee approved the study with EC Number: KMC/MNG/ IAEC/05-2018),

\section{Study period and location}

The study was conducted from June 2020 to December 2020 at Department of Biochemistry, Kasturba Medical College, Mangalore.

\section{Preparation of the $\boldsymbol{S}$. pinnata bark extract}

$S$. pinnata, bark was collected locally from Dakshina Kannada, and was identified and authenticated by Prof. Vasundhara Rao (retired professor), Department of Botany, Govt. College, Mangalore University and an ayurvedic physician.

We separated, shade-dried, and powdered the bark in a grinder. We extracted $100 \mathrm{~g}$ of the powder repeatedly with methanol $(30 \%)$ using the Soxhlet apparatus over $72 \mathrm{~h}$. We collected the concentrated bark extract and removed the solvent using a rotary evaporator. This semisolid extract was lyophilized and stored atroom temperature $\left(27-30^{\circ} \mathrm{C}\right)$ until use.

\section{Animals and groupings}

We procured 78 rats from the central animal house, Kasturba Medical College, Mangalore, India, and housed these in polypropylene cages with husk as bedding material and standard food and water ad libitum. We divided the rats into four groups, subdividing each into a, b, c, and d subgroup related to the time of sacrifice, as follows:

- Group-1: Normal control group;

- Group-2: Mucositis model (EP): Subdivided into 2a, 2b, 2c, and 2d;

- Group-3: S. pinnata control group (SP): Subdivided into $3 \mathrm{a}, 3 \mathrm{~b}, 3 \mathrm{c}$, and $3 \mathrm{~d}$; and

- Group-4: S. pinnata and mucositis treatment group $(\mathrm{EP}+\mathrm{SP})$ : Subdivided into $4 \mathrm{a}, 4 \mathrm{~b}, 4 \mathrm{c}$, and $4 \mathrm{~d}$.

- We considered the time of etoposide injection as $0 \mathrm{~h}$ and then calculated the time of exposure.

For Group 1, rats without any treatment and housed at normal temperature, humidity, and normal dietary conditions were considered as normal controls. For Group 2, mucositis was developed by etoposide administration in a single dose $(65 \mathrm{mg} / \mathrm{kg}$ bodyweight) by intraperitoneal injection. Group 3 received $200 \mathrm{mg} / \mathrm{kg}$ bodyweight of $S$. pinnata bark extract once a day at $0,24,48$, and $72 \mathrm{~h}$. Group 4 was treated with $S$. pinnata once a day at $0,24,48$, and $72 \mathrm{~h}$, after EP administration and was considered as the treatment group. Animals were sacrificed at 24, 48,72 , and $96 \mathrm{~h}$ after intervention by euthanasia followed by cervical dislocation.

\section{Biochemical estimations}

After sacrifice, the intestine was dissected, and $10 \%$ tissue homogenate was preparedusing phosphate-buffered saline, except for $\mathrm{Na}^{+}-\mathrm{K}^{+}$ATPase, for which the tissue homogenate was prepared using a sucrose buffer.

1. Estimation of $\mathrm{Na}^{+}-\mathrm{K}^{+}$ATPase activity: The method adopted was that by Adam-Vizi and Seregi [16] in which activity was calculated by the difference between the two assays. One unit of enzyme activity is expressed as U/L.

2. Estimation of MPO activity: The method adopted was described bySuchitra et al. [17] the enzyme activity is expressed as $\mathrm{U} / \mathrm{L}$. 
3. Estimation of NO levels: The method adopted was described by Menaka et al. [18]. The level of NO is expressed as $\mathrm{mg} / \mathrm{g}$ of tissue.

4. Estimation of reduced GSH: The method adopted was described by Ellman using DTNB. The values are expressed as $\mathrm{mg} / \mathrm{g}$ of tissue [19].

5. Estimation of TAO: The method adopted was described by Korecevic et al. [20] activity is expressed as $\mathrm{mM} / \mathrm{L}$.

\section{Statistical analysis}

Normal data are expressed as mean \pm standard error of the mean. Non-normal data are expressed as the median with a $95 \%$ confidence interval. We performed the statistical analysis usingEZR statistical software, version 1.54. (Jichi Medical University Saitama Medical Centre, Tokyo, Japan). We used one-way analysis of variance and the Kruskal-Wallis test for multiple comparisons and the Mann-Whitney $\mathrm{U}$ - and sample $t$-test to find the differences between groups, considering $\mathrm{p}<0.05$ as statistically significant.

\section{Results \\ MPO activity}

We observed a highly significant increase in MPO activity in the rats exposed to etoposide (Groups-2a, $2 \mathrm{~b}, 2 \mathrm{c}$, and $2 \mathrm{~d}$ ). MPO activity remained in the normal levels in the SP control groups (Groups-3a, 3b, 3c, and $3 \mathrm{~d}$ ), and recovery occurred in the $\mathrm{EP}+\mathrm{SP}$ groups (Groups-4a, 4b, 4c, and 4d; Table-1).

\section{NO levels}

A significant increase occurred in the EP groups over a period of 24-96 h. We observed an insignificant decrease in NO levels among the SP control groups over 24-96 $\mathrm{h}$ when compared with that of the normal control group. We also observed a significant decrease in NO levels in the EP+SP groups over 24-96 h. However, the levels remained high in the $\mathrm{EP}+\mathrm{SP}$ groups when compared with the SP and normal control groups. Surprisingly, the results showed that the $\mathrm{NO}$ levels remained higher in $\mathrm{EP}+\mathrm{SP} 24 \mathrm{~h}$ and $\mathrm{EP}+\mathrm{SP}$ $48 \mathrm{~h}$ than the EP $24 \mathrm{~h}$ and EP $48 \mathrm{~h}$ levels respectively (Table-2).

\section{TAO}

A significant decrease in TAO activity occurred among the EP groups over 24-96 h. We observed non-significant difference among the SP control groups sacrificed at different intervals and a significant increase in TAO activity in the $\mathrm{EP}+\mathrm{SP}$ groups over 24-96 h, which showed a tendency to return to the normal level at $96 \mathrm{~h}$. (Table-3).

\section{GSH levels}

A statistically significant, gradual decrease in GSH levels occurred in the EP groups, a significant increase in GSH levels occurred in the SP control groups over 24-96 h, and a gradual increase in GSH levels occurred in the $\mathrm{EP}+\mathrm{SP}$ groups, with progress over the time. The levels remained significantly low in the $\mathrm{EP}+\mathrm{SP} 24 \mathrm{~h}$ group in comparison with that of the normal control group; however, the levels had a tendency to increase toward normal (Table-4).

\section{$\mathrm{Na}^{+}-\mathrm{K}^{+}$ATPase activity}

We observed a more than $50 \%$ decrease in the enzyme activity after $24 \mathrm{~h}$, followed by a sudden increase in the activity after $48 \mathrm{~h}$, with gradual hike at 72 and $96 \mathrm{~h}$ in the EP groups as compared with the other groups (Table-5).

\section{Discussion}

Cytotoxicity is a major side effect of chemotherapy. Inflammation and mucosal tissue injury are attributed to cytotoxicity. In addition, etoposide induces a severe form of mucositis, during which ROS generation triggered by etoposide leads to an inflated inflammatory response $[3,4,21]$. Redox homeostasis

Table-1: MPO activity.

\begin{tabular}{|c|c|c|c|}
\hline & $\begin{array}{l}\text { MPO activity }(U / L) \\
\text { (Mean } \pm \text { SEM) } \\
\end{array}$ & \multirow{2}{*}{$\begin{array}{l}\text { p-value between individual } \\
\text { groups and normal group by } \\
\text { independent sample t-test }\end{array}$} & \multirow{2}{*}{$\begin{array}{l}\text { p-value between EP, } \\
\text { SP, and EP+SP groups, } \\
\text { respectively, by ANOVA }\end{array}$} \\
\hline Normal (1) & $56.67 \pm 6.97$ & & \\
\hline EP 24 h (2a) & $53.22 \pm 9.01$ & 0.767 & $<0.001 *$ \\
\hline EP 48 h (2b) & $89.27 \pm 7.38$ & $0.00861 *$ & \\
\hline EP 72 h (2c) & $91.71 \pm 6.04$ & $0.00486 *$ & \\
\hline EP 96 h (2d) & $97.19 \pm 4.38$ & $<0.001 *$ & \\
\hline SP 24 h (3a) & $54.13 \pm 1.04$ & 0.727 & $0.0017^{*}$ \\
\hline SP 48 h (3b) & $53.02 \pm 0.51$ & 0.614 & \\
\hline SP 72 h (3c) & $41.01 \pm 1.79$ & 0.055 & \\
\hline SP 96 h (3d) & $39.48 \pm 0.79$ & $0.0344 *$ & \\
\hline $\mathrm{EP} \pm \mathrm{SP} 24 \mathrm{~h}(4 \mathrm{a})$ & $68.44 \pm 2.18$ & 0.138 & 0.255 \\
\hline$E P \pm S P 48 h(4 b)$ & $66.26 \pm 3.88$ & 0.258 & \\
\hline $\mathrm{EP} \pm \mathrm{SP} 72 \mathrm{~h}(4 \mathrm{c})$ & $62.46 \pm 2.54$ & 0.453 & \\
\hline $\mathrm{EP} \pm \mathrm{SP} 96 \mathrm{~h}(4 \mathrm{~d})$ & $58.05 \pm 3.33$ & 0.872 & \\
\hline \multicolumn{3}{|c|}{ Comparison between normal and $24 \mathrm{~h}$ after treatment groups } & 0.161 \\
\hline \multicolumn{3}{|c|}{ Comparison between normal and $48 \mathrm{~h}$ after treatment groups } & $<0.001^{*}$ \\
\hline \multicolumn{3}{|c|}{ Comparison between normal and $72 \mathrm{~h}$ after treatment groups } & $<0.001 *$ \\
\hline \multicolumn{3}{|c|}{ Comparison between normal and 96 h after treatment groups } & $<0.001^{*}$ \\
\hline
\end{tabular}

$\mathrm{MPO}=$ Myeloperoxidase, $\mathrm{SEM}=$ Standard error of the mean, ANOVA=Analysis of variance 
Table-2: Nitric oxide levels.

\begin{tabular}{|c|c|c|c|}
\hline Groups & $\begin{array}{c}\text { NO concentration } \\
\text { (mg/g tissue }) \\
(\text { Mean } \pm \text { SEM }) \\
\end{array}$ & \multirow[t]{2}{*}{$\begin{array}{l}\text { p-value between individual } \\
\text { groups and normal group by } \\
\text { independent sample t-test }\end{array}$} & \multirow[t]{2}{*}{$\begin{array}{l}\text { p-value between EP, } \\
\text { SP, and EP+SP groups, } \\
\text { respectively, by ANOVA }\end{array}$} \\
\hline Normal (1) & $14.35 \pm 0.77$ & & \\
\hline EP 24 h $(2 a)$ & $18.42 \pm 0.64$ & $0.00597 *$ & $<0.001 *$ \\
\hline EP $48 \mathrm{~h}(2 \mathrm{~b})$ & $28.33 \pm 0.33$ & $<0.001 *$ & \\
\hline EP 72 h $(2 c)$ & $67.87 \pm 3.57$ & $<0.001 *$ & \\
\hline EP 96 h $(2 d)$ & $98.82 \pm 2.19$ & $<0.001 *$ & \\
\hline SP 24 h (3a) & $12.51 \pm 1.33$ & 0.26 & 0.396 \\
\hline SP $48 \mathrm{~h}(3 \mathrm{~b})$ & $12.37 \pm 0.54$ & 0.0638 & \\
\hline SP 72 h (3c) & $11.295 \pm 0.53$ & $0.00878 *$ & \\
\hline SP 96 h (3d) & $11.205 \pm 0.35$ & $0.0042 *$ & \\
\hline $\mathrm{EP} \pm \mathrm{SP} 24 \mathrm{~h}(4 \mathrm{a})$ & $70.02 \pm 3.9$ & $<0.001^{*}$ & $<0.001^{*}$ \\
\hline$E P \pm S P 48$ h (4b) & $57.10 \pm 5.63$ & $<0.001 *$ & \\
\hline $\mathrm{EP} \pm \mathrm{SP} 72 \mathrm{~h}(4 \mathrm{c})$ & $53.37 \pm 4.90$ & $<0.001 *$ & \\
\hline$E P \pm S P 96 h(4 d)$ & $47.736 \pm 2.72$ & $<0.001 *$ & \\
\hline \multicolumn{3}{|c|}{ Comparison between normal and $24 \mathrm{~h}$ after treatment groups } & $<0.001 *$ \\
\hline \multicolumn{3}{|c|}{ Comparison between normal and $48 \mathrm{~h}$ after treatment groups } & $<0.001^{*}$ \\
\hline \multicolumn{3}{|c|}{ Comparison between normal and $72 \mathrm{~h}$ after treatment groups } & $<0.001 *$ \\
\hline \multicolumn{3}{|c|}{ Comparison between normal and $96 \mathrm{~h}$ after treatment groups } & $<0.001 *$ \\
\hline
\end{tabular}

$\mathrm{NO}=$ Nitric oxide, SEM=Standard error of the mean, ANOVA=Analysis of variance

Table-3: TAO activity.

\begin{tabular}{|c|c|c|c|}
\hline Groups & $\begin{array}{l}\text { TAO activity } \\
(\mathrm{mM} / \mathrm{L}) \\
(\text { Mean } \pm \text { SEM })\end{array}$ & $\begin{array}{l}\text { p-value between individual } \\
\text { groups and normal group by } \\
\text { independent sample t-test }\end{array}$ & $\begin{array}{c}\text { p-value between EP, SP, and } \\
\text { EP+SP groups, respectively, } \\
\text { by ANOVA }\end{array}$ \\
\hline Normal (1) & $8.91 \pm 0.13$ & & \\
\hline EP 24 h $(2 a)$ & $8.0 \pm 0.2$ & $0.00463 *$ & $<0.001^{*}$ \\
\hline EP 48 h (2b) & $6.52 \pm 0.16$ & $<0.001 *$ & \\
\hline EP 72 h $(2 c)$ & $4.58 \pm 0.08$ & $<0.001 *$ & \\
\hline EP 96 h $(2 d)$ & $2.72 \pm 0.31$ & $<0.001 *$ & \\
\hline SP 24 h (3a) & $8.48 \pm 0.14$ & 0.0518 & $0.0272 *$ \\
\hline SP 48 h (3b) & $8.96 \pm 0.09$ & 0.771 & \\
\hline SP 72 h (3c) & $8.98 \pm 0.10$ & 0.708 & \\
\hline SP 96 h (3d) & $9.01 \pm 0.08$ & 0.708 & \\
\hline $\mathrm{EP} \pm \mathrm{SP} 24 \mathrm{~h}(4 \mathrm{a})$ & $6.73 \pm 0.2$ & $<0.001 *$ & $<0.001 *$ \\
\hline $\mathrm{EP} \pm \mathrm{SP} 48 \mathrm{~h}(4 \mathrm{~b})$ & $7.55 \pm 0.14$ & $<0.001 *$ & \\
\hline $\mathrm{EP} \pm \mathrm{SP} 72 \mathrm{~h}(4 \mathrm{c})$ & $8.36 \pm 0.10$ & $0.00885^{*}$ & \\
\hline$E P \pm S P 96$ h (4d) & $8.60 \pm 0.04$ & 0.0794 & \\
\hline \multicolumn{3}{|c|}{ Comparison between normal and $24 \mathrm{~h}$ after treatment groups } & $<0.001^{*}$ \\
\hline \multicolumn{3}{|c|}{ Comparison between normal and $48 \mathrm{~h}$ after treatment groups } & $<0.001^{*}$ \\
\hline \multicolumn{3}{|c|}{ Comparison between normal and $72 \mathrm{~h}$ after treatment groups } & $<0.001 *$ \\
\hline \multicolumn{3}{|c|}{ Comparison between normal and $96 \mathrm{~h}$ after treatment groups } & $<0.001^{*}$ \\
\hline
\end{tabular}

TAO=Total antioxidant, SEM=Standard error of the mean, ANOVA=Analysis of variance

decides the effect of ROS on macromolecules, including nucleic acids, proteins, and enzymes.

DNA damage is a key process that affects the cell cycle at different levels. The changes during the development of mucositis highlight ROS-sensitive sequences, which elicit the inflammatory mechanisms. ROS stimulates the assembly of leucocytes in the damaged tissue, actuating neutrophil production. Activated neutrophils escalate the production of inflammatory marker MPO, a hemoprotein stored in the leukocyte granules. This increase is the basis for the inflammation due to ROS [22].

In the present study, we found an insignificant initial decrease in MPO activity at $24 \mathrm{~h}$ after etoposide exposure, which looks accidental and yet interesting. However, a sharp increase at $48 \mathrm{~h}$ and a subsequent increase thereafter can be regarded as aggravated mucositis. MPO catalyzes oxidation of the phenolic ring of etoposide to yield phenoxyl radical as shown below [23].

Etoposide- $\mathrm{OH}+\mathrm{RO}_{2}$ Etoposide-- $\mathrm{O}^{\bullet}+\mathrm{RO}_{2} \mathrm{H}$

Etoposide--O $+\mathrm{RH}$ Etoposide- $\mathrm{OH}+\mathrm{R}^{\bullet}$

The dip in the observed MPO levels could be caused by the time taken by etoposide metabolism, and an increase in the levels could be due to the enhanced radical production as a result of this metabolism. This mechanism increases the existing free radical pool to augment the propagating chain reaction that leads to the amplification of pro-inflammatory cytokines. Thus, formation of phenoxyl radicals from the etoposide parallels the increase in MPO activity at a later stage, as seen in our study. This finding also is corroborated by Atwal et al. [24] who have shown that MPO added to the etoposide-induced DNA damage through free radical toxicity. 
Table-4: GSH levels.

\begin{tabular}{|c|c|c|c|}
\hline \multirow{2}{*}{$\begin{array}{l}\text { Groups } \\
\text { Normal (1) }\end{array}$} & \multirow{2}{*}{$\begin{array}{c}\begin{array}{c}\text { GSH levels }(\mathrm{mg} / \mathrm{g} \\
\text { tissue })(\text { Mean } \pm \text { SEM })\end{array} \\
206.54 \pm 5.64\end{array}$} & \multirow{2}{*}{$\begin{array}{l}\text { p-value (in comparison } \\
\text { with normal group) by } \\
\text { independent sample t-test }\end{array}$} & \multirow{2}{*}{$\begin{array}{c}\text { p-value between EP, SP, and } \\
\text { EP+SP groups, respectively, } \\
\text { obtained by ANOVA }\end{array}$} \\
\hline & & & \\
\hline EP 24 h $(2 a)$ & $169.66 \pm 2.98$ & $0.001 *$ & $<0.001 *$ \\
\hline EP 48 h (2b) & $148.16 \pm 4.72$ & $<0.001 *$ & \\
\hline EP $72 \mathrm{~h}(2 \mathrm{c})$ & $133.24 \pm 7.03$ & $<0.001 *$ & \\
\hline EP 96 h $(2 d)$ & $105.90 \pm 11.49$ & $<0.001 *$ & \\
\hline SP 24 h (3a) & $195.35 \pm 3.31$ & 0.118 & $<0.001 *$ \\
\hline SP $48 \mathrm{~h}(3 \mathrm{~b})$ & $200.95 \pm 5.18$ & 0.482 & \\
\hline SP $72 \mathrm{~h}(3 \mathrm{c})$ & $216.69 \pm 0.99$ & 0.107 & \\
\hline SP 96 h (3d) & $222.70 \pm 2.82$ & $0.0284 *$ & \\
\hline$E P \pm S P 24$ h (4a) & $109.59 \pm 4.02$ & $<0.001 *$ & $<0.001 *$ \\
\hline $\mathrm{EP} \pm \mathrm{SP} 48 \mathrm{~h}(4 \mathrm{~b})$ & $132.17 \pm 1.88$ & $<0.001^{*}$ & \\
\hline$E P \pm S P 72$ h $(4 c)$ & $142.53 \pm 1.77$ & $<0.001^{*}$ & \\
\hline$E P \pm S P 96 h(4 d)$ & $159.60 \pm 2.62$ & $<0.001^{*}$ & \\
\hline \multicolumn{3}{|c|}{ Comparison between normal and $24 \mathrm{~h}$ after treatment groups } & $<0.001^{*}$ \\
\hline \multicolumn{3}{|c|}{ Comparison between normal and $48 \mathrm{~h}$ after treatment groups } & $<0.001 *$ \\
\hline \multicolumn{3}{|c|}{ Comparison between normal and $72 \mathrm{~h}$ after treatment groups } & $<0.001 *$ \\
\hline \multicolumn{3}{|c|}{ Comparison between normal and $96 \mathrm{~h}$ after treatment groups } & $<0.001 *$ \\
\hline
\end{tabular}

$\mathrm{GSH}=$ Glutathione, SEM=Standard error of the mean, ANOVA=Analysis of variance

Table-5: $\mathrm{Na}^{+}-\mathrm{K}^{+}$ATPase activity.

\begin{tabular}{|c|c|c|c|}
\hline Groups & $\begin{array}{l}\mathrm{Na}^{+}-\mathrm{K}^{+} \mathrm{ATPase} \\
\text { activity (U/L) } \\
\text { Median }(\mathrm{Q1}, \mathrm{Q2})\end{array}$ & \multirow{2}{*}{$\begin{array}{c}\text { p-value between individual } \\
\text { groups and normal group } \\
\text { obtained by Mann-Whitney } \\
\text { U-test }\end{array}$} & \multirow{2}{*}{$\begin{array}{c}\text { p-value between EP, SP, and } \\
\text { EP+SP groups, respectively, } \\
\text { obtained by Kruskal-Wallis rank- } \\
\text { sum test }\end{array}$} \\
\hline Normal (1) & $0.36(0.22,0.39)$ & & \\
\hline EP $24 \mathrm{~h}$ & $0.16(0.07,0.27)$ & 0.352 & $0.05 *$ \\
\hline EP $48 \mathrm{~h}$ & $0.47(0.23,1.31)$ & 0.36 & \\
\hline EP $72 \mathrm{~h}$ & $0.50(0.34,0.53)$ & 0.329 & \\
\hline EP $96 \mathrm{~h}$ & $0.67(0.60,0.88)$ & $0.00952 *$ & \\
\hline SP $24 \mathrm{~h}$ & $0.25(0.22,0.27)$ & 0.336 & 0.3215 \\
\hline SP $48 \mathrm{~h}$ & $0.27(0.24,0.28)$ & 0.378 & \\
\hline SP $72 \mathrm{~h}$ & $0.32(0.30,0.33)$ & 0.394 & \\
\hline SP $96 \mathrm{~h}$ & $0.32(0.25,0.36)$ & 0.873 & \\
\hline$E P \pm S P 24 h$ & $0.25(0.23,0.27)$ & 0.429 & $0.0275 *$ \\
\hline $\mathrm{EP} \pm \mathrm{SP} 48 \mathrm{~h}$ & $0.26(.24,0.27)$ & 0.394 & \\
\hline $\mathrm{EP} \pm \mathrm{SP} 72 \mathrm{~h}$ & $0.28(0.26,0.30)$ & 0.378 & \\
\hline$E P \pm S P 96 h$ & $0.36(0.34,0.38)$ & 0.927 & \\
\hline \multicolumn{3}{|c|}{ Comparison between normal and $24 \mathrm{~h}$ after treatment groups } & 0.5445 \\
\hline \multicolumn{3}{|c|}{ Comparison between normal and $48 \mathrm{~h}$ after treatment groups } & 0.651 \\
\hline \multicolumn{3}{|c|}{ Comparison between normal and $72 \mathrm{~h}$ after treatment groups } & 0.197 \\
\hline \multicolumn{3}{|c|}{ Comparison between normal and $96 \mathrm{~h}$ after treatment groups } & $0.0197 *$ \\
\hline
\end{tabular}

We found a decrease in the MPO levels in the mucositis model treated with $S$. pinnata over $96 \mathrm{~h}$, showing that this extract can be beneficial in treating the inflammation caused by chemotherapy. Catalytic activity of MPO also is influenced by NO in anaerobic conditions, and the increased activity of MPO decreases the bioavailability of $\mathrm{NO}$ for its normal functioning in the body [25]. This condition is evident in the present study.

In our study, we observed an increase in $\mathrm{NO}$ levels with the time of exposure to etoposide, emphasizing possible drug toxicity on the intestinal tissue to develop mucositis. Moreover, NO levels in the SP control groups corresponded to those of normal levels in rats and a decrease in the levels observed over $96 \mathrm{~h}$. These results provide evidence of the protective action of $S$. pinnata, as the NO levels showed a tendency toward normal in the mucositis groups treated with the extract. NO, synthesized by the action of iNOS, is a short-living molecule that can easily diffuse through the tissues [26]. iNOS activity has been found to increase with the administration of chemotherapeutic regimens such as 5-fluorouracil in the esophageal cells [27]. At a higher concentration, NO reacting with superoxide radicals can release peroxynitrate radicals, which can aggravate tissue injury and inflammation through cytokine-mediated reactions [28].

Worsened antioxidant levels can occur in patients receiving chemotherapy [29]. In the present study, the rat intestinal tissue showed a significant gradual depletion of the antioxidant status due to etoposide treatment over $96 \mathrm{~h}$, indicating oxidative constraint in the tissue along with the progress in time of exposure. In the SP control groups, we found an increase in antioxidant 
activity over 24-96 h, reflecting the antioxidant potential of $S$. pinnata. This finding is similar to that by Kumar, in which $S$. pinnata fruit showed high radical scavenging activity attributed to its phenolic and tannin content [30]. Our study also showed that treatment with this extract could maintain TAO at levels similar to those in normal control group, which could be due to the presence of the above-mentioned compounds that we observed during the component analysis, thus highlighting anti-mucositic effects. In addition, the analyzed GSH levels support this observation.

GSH shows a wide range of paradigms in cancer therapies $[31,32]$. In the current study, the intestinal GSH levels significantly decreased along with the increase in time after etoposide administration, indicating the loss of antioxidant potential in the rat intestinal tissue. We observed sustained GSH levels in the groups of rats exposed to etoposide and treated with $S$. pinnata. Our findings are supported by evidence from Iqbal et al. [33], in which $S$. pinnata bark extract attenuated the ethanol-induced hepatotoxicity, as well as by those from our previous study, reinforcing the maintained normal TAO levels of the same group [34].

Development of diarrhea is a key feature during mucositis, caused by the altered ionic status of the cellular environment. Maintenance of the chemical and electrical gradient between intra- and extra-cellular spaces is primarily done by $\mathrm{Na}^{+}-\mathrm{K}^{+}$ATPase [35]. In our study, we observed a dip in the activity of intestinal $\mathrm{Na}^{+}-\mathrm{K}^{+}$ATPase at $24 \mathrm{~h}$ after etoposide administration and also saw a parallel enhancement in inflammatory status. An interesting finding is an eventual rise in the level over the $96 \mathrm{~h}$ of administration, which could be attributed to the increased cellular destruction due to mucositis. Evidence from the literature also indicates that both the phosphorylation of amino acid residues and the localization of $\alpha$-subunit of the enzyme can lead to its increased activity [36]. Nevertheless, treatment with $S$. pinnata along with etoposide showed that the conservation of the sodium pump activity can ensure the protective action of this bark extract against tissue injury and inflammation.

\section{Conclusion}

Over the time, etoposide exposure causes oxidative stress-mediated mucosal tissue injury. The mechanisms discussed above, if monitored during chemotherapy, could be beneficial in curbing the general psychological and pathological burdens of the patient caused by mucositis and its consequences. Considering the basic needs of patients such as difficulty in consuming a proper diet, $S$. pinnata bark extract promises for minimizing the ill effects caused by chemotherapy and can help in planning further treatment strategies.

\section{Authors' Contributions}

GMR and MC: Research concept and design. GMR and AM: Collection and assembly of data, data analysis and interpretation, and writing the manuscript. MC: Expert advice for the concept and manuscript. All authors read, revised and approved the final manuscript.

\section{Acknowledgments}

The authors are thankful to the Department of Biochemistry, Kasturba Medical College, Mangalore, Manipal Academy of Higher Education, India, for the facilities provided for the study. The authors did not receive any funds for this study.

\section{Competing Interests}

The authors declare that they have no competing interests.

\section{Publisher's Note}

Veterinary World remains neutral with regard to jurisdictional claims in published institutional affiliation.

\section{References}

1. Berger, K., Schopohl, D., Bollig, A., Strobach, D., Rieger, C., Rublee, D. and Ostermann, H. (2018) Burden of oral mucositis: A systematic review and implications for future research. Oncol. Res. Treat., 41(6): 399-405.

2. Montecucco, A., Zanetta, F. and Biamonti, G. (2015) Molecular mechanisms of etoposide. EXCLI J., 14(1): 95-108.

3. Sonis, S.T. (2004), Oral mucositis in cancer therapy. $J$. Suppl. Oncol., 6(2): 3-8.

4. Nihei, S., Sato, J., Komatsu, H., Ishida, K., Kimura, T., Tomita, T. and Kudo, K. (2018) The efficacy of sodium Azulene sulfonate L-glutamine for managing chemotherapy-induced oral mucositis in cancer patients: A prospective comparative study. J. Pharm. Health Care Sci., 4(1): 20.

5. Rahnama, M., Madej-Czerwonka, B., JastrzębskaJamrogiewicz, I. and Jamrogiewicz, R. (2015) Analysis of the influence of parenteral cancer chemotherapy on the health condition of oral mucosa. Contemp. Oncol. (Pozn), 19(1): 77-82.

6. Villa, A. and Sonis, S.T. (2015) Mucositis: Pathobiology and management. Curr. Opin. Oncol., 27(3): 159-164.

7. Poulopoulos, A., Papadopoulos, P. and Andreadis, D. (2017) Chemotherapy: Oral side effects and dental interventions a review of the literature. Stomatol. Dis. Sci., 1 : 35-49.

8. Kwon, Y. (2016) Mechanism-based management for mucositis: Option for treating side effects without compromising the efficacy of cancer therapy. Oncol. Targets Ther., 9: 2007-2016.

9. Skou, J.C. (1998) The identification of the sodium pump. Biosci. Rep., 24(4-5): 436-451.

10. Garcia, D.G., de Castro-Faria-Neto, H.C., da Silva, C.I., de Souza e Souza, K.F.c., Gonçalves-de-Albuquerque, C.F., Silva, A.R., da Fonte de Amorim, L.M., Freire, A.S., Santelli, R.E., Diniz, L.P., Gomes, F.C.A., de Castro Faria, M.V. and Burth, P. (2015) Na/K-ATPase as a target for anticancer drugs: Studies with perillyl alcohol. Mol. Cancer., 14: 105.

11. Pratt, R.D., Brickman, C.R., Cottrill, C.L., Shapiro, J.I. and Liu, J. (2018) The Na/K-ATPase signaling: From specific ligands to general reactive oxygen species. Int. J. Mol. Sci., 19(9): 2600.

12. Gonçalves-de-Albuquerque, C.F., Silva, A.R., da Silva, C.I., Castro-Faria-Neto, H.C. and Burth, P. (2017) Na/k pump and beyond: $\mathrm{Na} / \mathrm{K}$-ATPase as a modulator of apoptosis and autophagy. Molecules, 22(4): 578-596.

13. Lalla, R.V., Bowen, J., Barasch, A., Elting, L., Epstein, J. 
and Keefe, D.M. (2014) MASCC/ISOO clinical practice guidelines for the management of mucositis secondary to cancer therapy. Cancer, 120(1): 1453-1461.

14. Chaveli-López, B. and Bagán-Sebastián, J.V. (2016) Treatment of oral mucositis due to chemotherapy. J. Clin. Exp. Dent., 8(2): e201-209.

15. Poojary, V., Hegde, K. and Shabaraya, A.R. (2018) Pharmacological review on Spondias pinnata: The Indian hog plum. Int. J. Pharm. Chem. Res., 4(2): 141-145.

16. Adam-Vizi, V. and Seregi, A. (1982) Receptor independent stimulatory effect of noradrenaline on Na-K ATPase in rat brain homogenate: Role of lipid peroxidation. Bioch. Pharmacol., 31(13): 2231-2236.

17. Suchitra, T V, Zuhara, K F, (2008) Myeloperoxidase activity in infection complicated and uninfected diabetic patients, Ind. J. Biochem. Biophys., 45(3): 179-183.

18. Menaka, K., Ramesh, A., Thomas, B. and Kumari, N.S. (2009) Estimation of nitric oxide as an inflammatory marker in periodontitis. J. Ind. Soc. Periodont., 13(2): 75-78.

19. Ellman, G.L. (1959) Tissue sulfhydryl groups. Arc. Biochem. Biophys., 82(1): 70-77.

20. Korecevic, D., Koracevic, G., Djordjevic, V., Andrejevic, S. and Cosic, V. (2001) Method for the measurement of antioxidant activity in human fluids. J. Clin. Pathol., 54(5): 356-361.

21. Nemade, H., Chaudhari, U., Acharya, A., Hescheler, J., Hengstler, J.G., Papadopoulos, S. and Sachinidis, A. (2018) Cell death mechanisms of the anti-cancer drug etoposide on human cardiomyocytes isolated from pluripotent stem cells. Arch. Toxicol., 92(4): 1507-1524.

22. Phaniendra, A., Jestadi, D.B. and Periyasamy, L. (2015) Free radicals: Properties, sources, targets, and their implication in various diseases. Ind. J. Clin. Biochem., 30(1): $11-26$.

23. Khan, A.A., Alsahli, M.A. and Rahmani, A.H. (2018) Myeloperoxidase as an active disease biomarker: Recent biochemical and pathological perspectives. Med. Sci. (Basel), 6(2): 33-54.

24. Atwal, M., Lishman, E.L., Austin, C.A. and Cowell, I.G. (2017) Myeloperoxidase enhances etoposide and mitoxantrone-mediated DNA damage: A target for myeloprotection in cancer chemotherapy. Mol. Pharmacol., 91(1): 49-57.

25. Maiocchi, S.L., Morris, J.C., Rees, M.D. and Thomas, S.R. (2017) Regulation of the nitric oxide oxidase activity of myeloperoxidase by pharmacological agents. Biochem. Pharmacol., 135: 90-115.

26. McAdam, E., Haboubi, H.N., Forrester, G., Eltahir, Z., Spencer-Harty, S., Davies, C., Griffiths, A.P., Baxter, J.N. and Jenkins, G.J.S. (2012) Inducible nitric oxide synthase (iNOS) and nitric oxide (NO) are important mediators of reflux-induced cell signalling in esophageal cells. Carcinogenesis, 33(11): 2035-2043.

27. Barbosa, S.C.M., Pereira, V.B.M., Wong, D.V.T., Santana, A.P.M., Lucetti, L.T., Carvalho, L.L., Barbosa, C.R.N., Callado, R.B., Silva, C.AA., Lopes, C.D.H., Brito, G.A.C., Alencar, N.M.N. and LimaJúnior, R.C.P. (2019) Amifostine reduces inflammation and protects against 5-fluorouracil-induced oral mucositis and hyposalivation. Braz. J. Med. Biol. Res., 52(3): e8251.

28. Salim, T., Sershen, C.L. and May, E.E. (2016) Investigating the role of TNF- $\alpha$ and IFN- $\gamma$ activation on the dynamics of iNOS gene expression in LPS stimulated macrophages. PLoS One, 11(6): e0153289.

29. Mohan, A., Poulose, R., Gupta, T., Luthra, K., Pandey, R.M., Madan, K., Hadda, V. and Guleria, R. (2017) Impact of chemotherapy on symptom profile, oxidant-antioxidant balance and nutritional status in non-small cell lung cancer. Lung India, 34(4): 336-340.

30. Kumar, N. and Chaiyasut, C. (2017) Health promotion potential of vegetables cultivated in Northern Thailand: A preliminary screening of tannin and flavonoid contents, $5 \alpha$-reductase inhibition, astringent activity, and antioxidant activities. J. Evid. Based. Complement. Altern. Med., 22(4): 573-579.

31. Bansal, A. and Simon, M.C. (2018) Glutathione metabolism in cancer progression and treatment resistance. J. Cell Biol., 217(7): 2291-2298.

32. Alanazi, A.M., Mostafa, G.A.E. and Al-Badr, A.A. (2015) Glutathione. Profiles Drug Subst. Excip. Relat. Methodol., 40: 43-158.

33. Iqbal, S.S., Mujahid, M., Kashif, S.M., Badruddeen, M.K., Arif, M., Bagga, P., Akhtar, J. and Rahman, M.A. (2016) Protection of hepatotoxicity using Spondias pinnata by prevention of ethanol-induced oxidative stress, DNA-damage and altered biochemical markers in Wistar rats. Int. Med. Res., 5(4): 267-275.

34. Beena, S., Gayathri, R., Abhineetha, Niha, B., Preetika. and Sudarshan, R. (2016) Study of protective action of Spondias pinnata bark extract on rat liver and kidney against etoposide induced chemical stress. Pharmacognosy, 8(1): 24-27.

35. Clausen, M.V., Hilbers, F. and Poulsen, H. (2017) The structure and function of the Na,K-ATPase isoforms in health and disease. Front. Physiol., 8: 371.

36. Nepal, N., Arthur, S. and Sundaram, U. (2019) Unique regulation of Na-K-ATPase during growth and maturation of intestinal epithelial cells. Cells, 8(6): 593-608. 